\title{
Highlands Vulnerability to Cattle Rearing in Momo Division, North West Cameroon
}

\author{
Tassah Ivo Tawe \\ Department of Economics and Environmental Studies/ National Centre for Education, Ministry of Scientific Research and Innovation \\ Yaoundé, Yaoundé, Cameroon
}

\section{Email address:}

tasswise@yahoo.co.nz

\section{To cite this article:}

Tassah Ivo Tawe. Highlands Vulnerability to Cattle Rearing in Momo Division, North West Cameroon. Landscape Architecture and Regional Planning. Vol. 3, No. 1, 2018, pp. 10-15. doi: 10.11648/j.larp.20180301.12

Received: March 20,2018; Accepted: April 19, 2018; Published: May 18, 2018

\begin{abstract}
Highlands constitute high energy environments that accommodate wealth of ecological resources for the benefit of mankind. In exploiting these resources for economic fortunes, man has placed himself superior by employing unsustainable practices with the notion that these ecological reservoirs would continue to provide more and more resources unabated. Nature, however always has its way to resurrect from this mishap by sending feedbacks which undermine the very survival of mankind. It is therefore with regards to this that the ecological impulses transmitted by the highlands of Momo Division due to unsustainable practices signal a signpost that the harmonious nexus between man, environment and economic fortune is a call for concern. This paper therefore had as objective to examine the nature of the highlands in Momo Division and how they impact on the cattle population. It equally focused on examining the local management strategies adopted by the pastoralists amidst observed retreating rangelands. In achieving these goals, the study adopted the descriptive and analytical methods of investigation. Vital primary data were generated through field observations, interviews and focused group discussions while secondary data involved the use of published and unpublished works and internet sources. The results obtain indicate that the highlands are under intense pressure from cattle rearing, settlement expansion and the forces of nature. The grazing fields are equally retreating due to the invasion of the rangelands by the bracken fern and other unpalatable species of fodder. The study reveals that the pastoralists are adapting to these changes through mobility, paddocking and pasture regeneration. However, it is noted that the present adaptation and innovation strategies employed lives much to be desired and therefore recommends government action through sensitization, training, seminars, workshops and financial assistance to the pastoralists.
\end{abstract}

Keywords: Highlands, Constraints, Vulnerability, Sustainability, Cattle Rearing, Momo Division

\section{Introduction}

Highlands sometimes consider as harsh, inhospitable and even wastelands [1] represent one of the most diverse ecosystems in the world. They further noted that these are high energy environment that accommodate genetic resources, provides food and fibre, serve as habitats to endemic species of plants and animals and equally provide spiritual, medicinal and aesthetic values to communities adjacent these environments.

In Cameroon, most highlands do not only play host to human settlement and agriculture but equally serve as grazing land for cattle rearing. Their exploitation for social and economic benefits has resulted in a declining trend in the services they provide to humanity as this is sometimes done with impunity. According to [2], changes in the ecological potentials of these highlands may sometimes exceed maximum threshold limits and cause permanent changes in the ecological site with significant implications on the cattle rearing industry. In this case, pastoralists may sometimes have to compete for a shrinking grazing land resource as it is the case in the highlands of Momo Division.

\section{The Problem}

Highlands are important ecosystems that support the growth and development of different natural vegetation and equally serve as habitat for wildlife and cattle rearing [3]. Their increasing exploitation and vulnerability calls to mind the need to sustainably manage these particular ecosystems as most communities which depend on them for basic livelihoods are becoming vulnerable as a result of 
unsustainable exploitation and over grazing.

In Momo Division, the highlands are considered by the local farming population as waste lands since they cannot sustainably managed these areas for agricultural production. In these circumstances therefore, they are passed as zones for cattle grazing and other forms of livestock such as sheep and goats. However, the demands of the growing population for fuel wood, fibre, medicinal purposes and the persistent encroachment of settlements into some parts of the highlands which are cattle grazing zones like Mbengwi, Oshie, Tugie and parts of the Upper Menka is gradually reducing the spatial extent of the rangelands. Equally, the methods observed in the grazing activity are oriented toward achieving short term pasture/cattle yields without sustainable measures for the rangeland management. As part of the adaptation strategies to cope in the mist of these growing challenges of retreating and degrading rangelands, the pastoralists have resorted to opportunistic mobility in which the traditional transhumance is the order of the day.

Another growing challenge faced on the rangelands is the notion of the common property resource [4]. The rangelands are regarded as common property resource and therefore, the desire to increase cattle numbers has been accompanied by unsustainable traditional practices such as bush burning. This is an adaptation strategy which according to the Fulani cattle rearers is believed would result to the eradication of the bracken fern which is an invasive and unpalatable specie of grass on the rangeland. It is equally believed that burning of the rangelands during the drier season will lead to the sprouting of fresh grass with the approach of the rainy season. Unfortunately, the bracken fern seems to be resilient and invading much of the rangelands. Prolonged burning and overgrazing on the steeper slopes of Ngwo, Menka and Tugie have been observed to be the reason for the declining biomass density and low pasture productivity in the study area.

Over grazing on the relatively small rangeland is another constraint to the cattle industry in Momo Division. It has made the effects of trampling very pronounced on the rangelands with some sections unable to reconstitute their pasture and the development of erosion channels with some large enough to cause slope failures. With all the problems affecting cattle, sheep and goats rearing on the highlands of Momo Division, determinism to survive on these rangelands seems to be a virtue uphold by the traditional cattle breeders as they make use of the most unsustainable methods at their disposal to improve on their flocks. This is sometimes accompanied by conflicts between farmers and graziers as they seek for grazing havens in the valleys during the dry season when the grass on the highlands must have been scotched by the sun.

This paper therefore has as objective to examine the nature of the highlands in Momo Division and how they impact on the livestock population. It equally focused on examining the local management strategies adopted by the pastoralists amidst the observed retreating rangelands.

\section{The Study Site}

Momo Division is one of the seven Divisions that make up the North West Region in the Western Highlands of Cameroon. It is located between longitudes $9^{0} 58^{\prime \prime}$ and $28^{\circ} 02^{\prime \prime}$ East of the Greenwich meridian and latitudes $5^{0} 54^{\prime \prime}$ and $1^{0} 91$ " North of the equator. Relatively, the division shares its borders with Menchum Division in the North and Mezam in the East. It equally shares an extensive border with the Southwest Region covering the Northwest, West and the Southwest of the study area. It has a total land surface of $1792 \mathrm{~km}^{2}$. The division is peopled by the Widikum tribe. The area is equally characterized by highlands and lowlands. The highlands are predominantly mountains and hills with steep slopes which often are less extensive due to the numerous accidental incised valley systems [1]. Also V-shaped valleys, deep and steep sided gorges and cascading waterfalls are common features. The occurrence of mountains is sporadic in the whole of the area extending from the Bamenda fault scarp, Tugie, Oshie and the Menka axis.

\section{Methodology}

The study is based on a field work carried out in December 2017 in Momo Division. It adopts both the descriptive and analytical methods of investigations and further complimented by interviews and focused group discussions with the Fulani cattle rearers in the highlands zones of the study area. The paper make use of the concept of Sustainable Adaptive Capacity proposed by [5] which is a paradigm shift in sustainable development and community wellbeing as the communities resort to adaptive measures in coping with the challenges on land and the dynamics in land use decision making. In this case therefore, sustainability according to this study has been defined as a measure of the relationship between the community as learners and their immediate environment rather than an externally designed policy to be achieved as observed in the study area. Equally, vital secondary data were generated through review from both published and unpublished works, internet and some grey literature. The results obtained were analyzed and presented in the form of tables and figures.

\section{Conceptual Framework}

The concept used in this study is that of Sustainable Adaptive Capacity which seeks to provide measures aimed at coping with the challenges on the highlands of Momo Division.

\section{The Concept of Sustainable Adaptive Capacity}

This concept combines the notion of Sustainability and that of Adaptive Capacity. It is a paradigm shift in sustainable development and community wellbeing which emphasized the need for a community to adopt adaptive 
measures in coping with the challenges on land, land use and the changing dynamics of land use decision making.

In this regard therefore, sustainability is a measure of the relationship between the community as learners and their immediate environments rather than an externally design goal to be achieved [5]. For sustainability to be efficient there is need for the society to adopt learning strategies that will accommodate feedbacks from changing exigencies in the environment with improved ability to enable decision making through the sharing of information, communication and understanding. This brings to the fore the concept of Sustainable Adaptive Capacity. Communities are not only to adapt to changes in the environment or in policies and decisions but should do so sustainably such that their activities will incorporate the short term needs of the world's poor with the long term concerns of the society and in changing the direction of international development efforts as noted by [6]

Generally, sustainability serves as a theme for both environmentalists and agricultural scientists. According to [7], sustainability is increasingly viewed as a desired goal of development and environmental management. This term has been used in many disciplines and in different contexts. The meaning therefore is dependent on the context in which it is applied and whether its use is based on a social, economic or ecological perspective. Sustainability maybe defined broadly or narrowly but a useful definition must specify explicitly the context as well as the temporal and spatial scale being considered. Also at the Rio Conference of 1992, the concept of sustainable management was a major theme and it was noted that land resources are to be managed for whatever purpose they are intended for and considerations are to be taken to safeguard for future need if necessary.

Adaptive Capacity on the other hand is the capacity of a system if the environment where the system exists is changing. In a more strict sense, [8] using a generic framework define Adaptive Capacity of a socio-ecological system (SES), to involve two main components; the capacity of the system to cope with and be able to maintain or improve on its state in the face of environmental changes. Secondly, the capacity to improve on its state, in relation to its environment to which it is adapted.

Generally, the concept of sustainability summarizes sustainability as a concept which seeks the desired goals of development and environmental management over space and time to the benefit of both the bio-physical and human environment. Sustainable Adaptive Capacity goes beyond development goals and environmental management but encompasses the potentials or capabilities of the said system to adapt to changing environmental events as well as adapting to new decisions, making an external policy outcome that affect their wellbeing in time and space. Sustainable Adaptive Capacity as a concept within this study is used to bring out existing adaptive measures, coping strategies in decision making, strengthening of the community ability to challenge its own established ways of thinking and doing things and to successively craft and adopt more effective distinct forms of performance enhancing organizational capacity and adaptive capacity.

\section{Results and Discussions}

The results of the study presented are geared toward providing solutions to the observed problems on the cattle population in the highlands of Momo Division of the North West Region of Cameroon.

\subsection{The Nature of the Highlands in Momo Division}

From field observations, the highlands of the area remain the most outstanding creation of forces of nature. They are characterized by abrupt relief forms and slopes which hardly portray homogeneity on space. Running water has acted severely in dissecting the landscape into deep incised valley, steep sided gorges and cascading waterfalls which now constitutes a conspicuous relief characteristic.

The area has an altitudinal variation that ranges from about $185 \mathrm{~m}$ above sea level in the southwest section toward the Mamfe basin to about $2035 \mathrm{~m}$ in the northeast. Three relief zones are distinguish based on altitudinal variations and relief configuration. These include; the more mountainous northnortheastern region with heights generally above $1000 \mathrm{~m}$, the undulating central-southwestern section punctuated by troughs/hills of heights less than $1000 \mathrm{~m}$ above sea level and the lowland relief area which is a narrow strip of plain in the southeast through which the major river (Momo) drains (Figure 1).

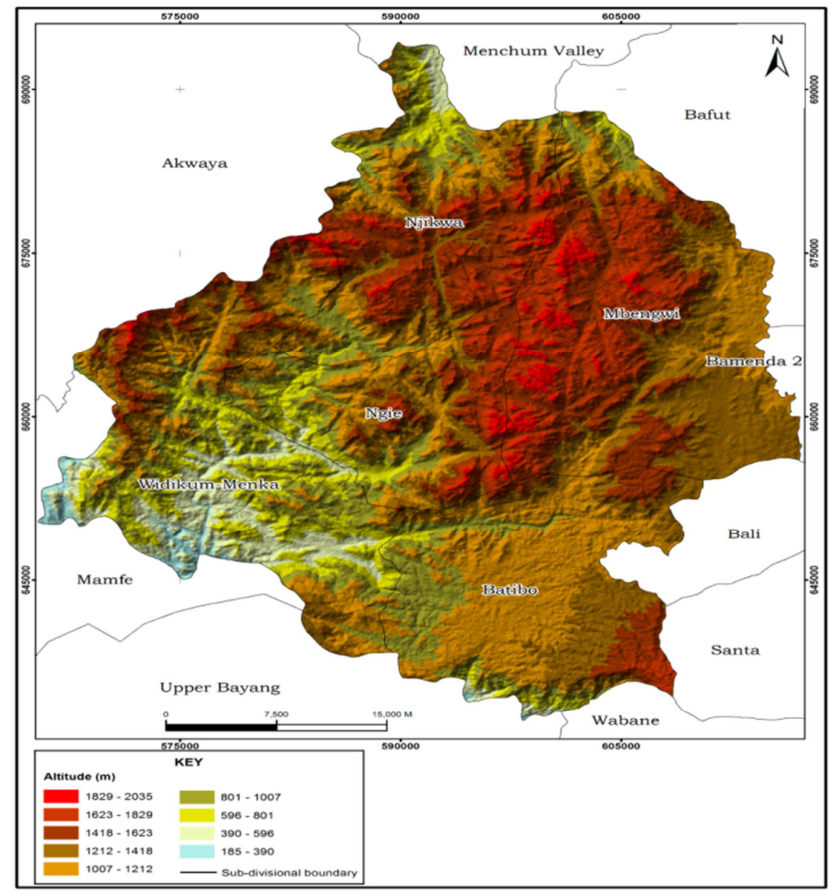

Figure 1. A Digital Elevation Model for Momo Division showing the major relief zones.

Source: Global Land Cover Facilities/ Landsat MSS, February 1976/ National Institute of Cartography, Yaoundé 
From figure 1, the landscape is generally characterized by the outcrop of huge rock masses and hills especially in the northern zone which portray different slope angles from the convex to the very steep, gentle and concave slopes at the river valleys. Approximately $78.78 \%$ of the landscape consists of highlands while the lowland relief covers $21.22 \%$ (Table 1)

Table 1. Proportions of lowlands to highlands in Momo Division.

\begin{tabular}{lll}
\hline Nature of land & Area in hectares (ha) & Percentage (\%) \\
\hline Lowlands & 38048 & 21.22 \\
Intermediate highlands & 58937 & 32.89 \\
Highlands & 82274 & 45.89 \\
\hline
\end{tabular}

Source: Derived from Figure 1

From Table 1, the topographic contrast in the landscape has made the relief of the region generally difficult. Table 1 shows a general land cover of 179258 ha. From this total figure, 38048ha $(21.22 \%)$ constitute the lowlands, 58937ha $(32.89 \%)$ is made up of the intermediate highlands which coincide to be areas of cattle grazing and settlement expansion while 82274 ha $(45.89 \%)$ constitute the extreme highlands. However, with a population density of $\left(77.39 \mathrm{p} / \mathrm{km}^{2}\right)$, the pressure on the available habitable land is enormous as the rush for economic fortunes and the scarcity of livelihoods assets is on the rise as the local communities still depend on the land to give life a meaning. In this case therefore, the pressure on the land cover especially on the high lands where cattle grazing takes place is on the rise. The increasing cattle, goats and sheep population has further accelerated pressure on the rangelands. The situation is further compounded by the view of [4] who noted that communal tendencies in land resource exploitation characterize the way of life of the people. In this case therefore, the economic strength of a family depends on how much land that can be brought under cultivation for a year even if they have to do so using the most unsustainable farming practices.

As indicated on table 1, the available low lying areas have been over exploited due to high pressure on scares resources. It is worthy to note that a significant proportion of the land $(45.89 \%)$ is made up of highlands which are extremely hostile and regarded as "a no go zone" for human activities nor cattle rearing. This further explains why the area has remained enclave since infrastructural development especially roads is a major challenge. The ecological niches are also very fragile since any imbalance on the slopes especially through vegetation clearance and mass movement processes make reconstitution difficult. The hilly nature of the landscape has also made agricultural development difficult and very unsustainable, initiating higher rates of surface wash processes and landslides. This is common especially in Menka, Ngie and parts of Njikwa. According to [9], though the relief of the area remains problematic, it exhibits huge diversity which with improved technology, land-use planning and resource conservation can supports a vibrant tourism sector for the growth and prosperity of the area and its people.

\subsection{Cattle Grazing Constraints on the Highlands}

A range of physical and human conditions were verified as constraints to cattle production on the highlands of Momo Division. Table 2 present field observations on some of the constraints to cattle rearing in the study area.

Table 2. Cattle grazing constraints in Momo Division.

\begin{tabular}{ll}
\hline $\begin{array}{l}\text { Grazing } \\
\text { constraints }\end{array}$ & Observation \\
\hline $\begin{array}{l}\text { The physical } \\
\text { landscape }\end{array}$ & $\begin{array}{l}\text { The area has numerous rock outcrops, delicate steep } \\
\text { slopes and incised valley system which has restricted } \\
\text { cattle movement and rangeland expansion. } \\
\text { Most of the pasture along the concave foot slopes is } \\
\text { not suitable for cattle. The long dry season causes the } \\
\text { pasture to be scourged } \\
\text { Veterinary officials are not regular to treat the animals } \\
\text { from diseases. } \\
\text { Inadequate } \\
\text { disease control }\end{array}$ \\
$\begin{array}{l}\text { Land use conflict } \\
\text { threat to the grazing activity. } \\
\text { The graziers are deficient in capital resource to invest } \\
\text { in ranching, pasture regeneration and research to get } \\
\text { the high yielding and resistant species as well as to } \\
\text { adequately treat their cattle against animal diseases. }\end{array}$ \\
\hline
\end{tabular}

Source: Field survey, 2016

Over grazing on the relatively small rangeland is another main constraint. It has made the effects of trampling very pronounced on the rangeland. It has also caused some sections unable to reconstitute their pasture and cause the development of erosion channels with some large enough to cause minor slope failures. The impacts of persistent burning of the highlands as a strategy for the sprouting of fresh pasture are enormous on rangeland management [10]. Burning results to long term modification of pasture where undesirable plant species for the cattle often gain resilience. Such species were observed to have invaded the eastern slopes of the Abakana plateau between Baraka and Atong villages in Menka, Njikwa and Ngie. Equally, prolonged burning and overgrazing on the steeper slopes with thin soils was observed to be responsible for their declining biomass productivity.

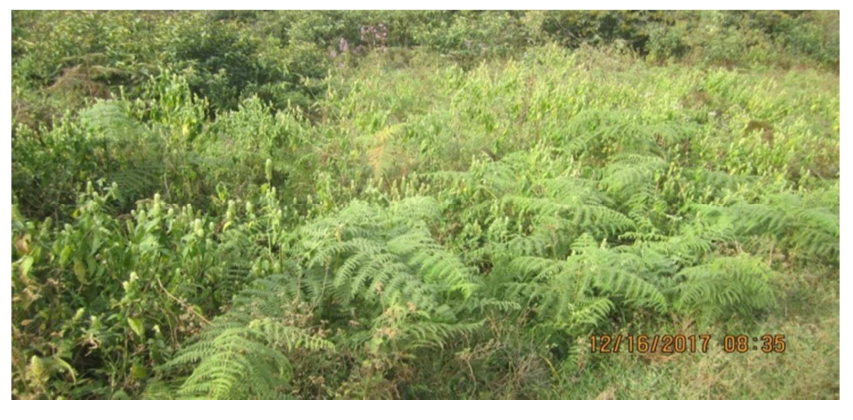

Source: Fieldwork (2017)

Figure 2. Rangeland invaded by the Bracken Fern in Menka.

Based on these issues, the study noted that the status of the rangeland has changed over time as shown on table 3 . 
Table 3. Grazing land, $N^{\circ}$. of animals, $N^{\circ}$. of graziers and animals stocking rate for Momo Division (2016).

\begin{tabular}{llllll}
\hline $\begin{array}{l}\text { Grazing } \\
\text { Land(ha) }\end{array}$ & $\begin{array}{l}\text { Grazing land invaded by the } \\
\text { bracken fern (ha) }\end{array}$ & Available grazing land (ha) & $\begin{array}{l}\text { Number of } \\
\text { graziers }\end{array}$ & $\begin{array}{l}\text { Total number of cattle, } \\
\text { sheep and goats }\end{array}$ & Stocking rate \\
\hline 105610 & 44179 & 61431 & 515 & $\mathbf{2 5 9 0 5 4}$ & 4.22 \\
$\%$ & $41.83 \%$ & $58.17 \%$ & - & - & \\
\hline
\end{tabular}

Source: Northwest Regional Delegation for Livestock, Fisheries and Animal Industries (2017)

From table 3, the cattle, sheep and goats population has been growing over the years. According to the Northwest Regional Delegation for Livestock, Fisheries and Animal Industries, the available grazing land as of 2016 was 105610ha. The total grazing land invaded by the bracken fern was 44179ha $(41.83 \%)$ while the available land for grazing was 61431 ha $(58.17 \%)$. However, the total available land for grazing for $2016(58.17 \%)$ ) is small relative to the total growing cattle, sheep and goats population (259054) in the study area.

It is equally observed from table 3 that the stocking rate of the animals (4.22) is high indicating that at least 4.22 numbers of cattle, sheep and goats are forced to feed on at most 1 ha of grazing land. In this case therefore, a decrease in 1ha of grazing land through invasion by the bracken fern will leads to 4.22 animals not having quality fodders to feed on. This has necessitated the animal breeders to resort to local intensification practices in order to ameliorate the situation as observed in the field. This goes to explain the recurrent farmer graziers conflicts experienced in the study area especially during the drier season when most of the fodder on the rangelands is scourged. Field observations indicate that the animal breeders have been intensifying efforts to meet up with this current challenge experienced on the rangelands.

\subsection{Coping Strategies on Rangelands in the Study Area}

Field observations indicate that significant transformations and diversification methods have been adopted by the Fulani cattle graziers on the rangelands. From the normal transhumance and free grazing practiced, fodder crops were observed to be cultivated to feed cattle, goats, and sheep on these highlands. The most common fodder crops identified in the field are Guatemala (Tripsacum laxum) and Bracharia. These fodder crops provides pasture to the animals especially during the drier season when the grass on the grazing field is scourged. This is equally a strategy to reduce the tension that usually takes place between the graziers and the farmers in the drier seasons.

Table 4. Pasteur improvement in Momo Division by the Divisional Delegation for Livestock, Fisheries and Animal Industries (2013-2016).

\begin{tabular}{|c|c|c|c|}
\hline Year & Type of pasture & Area established in (ha) & Exploitation methods \\
\hline \multirow{2}{*}{2013} & Bracharia & 10 & Grazing \\
\hline & Guatemala & 4 & Cutting \\
\hline \multirow{2}{*}{2014} & Bracharia & 12 & Grazing \\
\hline & Guatemala & 6 & Cutting \\
\hline \multirow{2}{*}{2015} & Bracharia & 15 & Grazing \\
\hline & Guatemala & 8 & Cutting \\
\hline 2016 & Bracharia & 17 & Grazing \\
\hline
\end{tabular}

Source: Northwest Regional Delegation for Livestock, Fisheries \& Animal Industries (2017)



Source: Fieldwork (2017)

Figure 3. Bags of Bracharia seeds serving as food for rodents at the Widikum Sub Divisional Delegation for Livestock.

In an attempt to investigate the process involved in the cultivation of these fodder crops, it was observed that most of the cattle graziers are still very ignorant with this innovation. The fodder crops for the animals are cultivated by the veterinary technicians in collaboration with a few cattle graziers who have been sensitized. This was mostly at the divisional headquarter of Mbengwi while cattle graziers in
Njikwa, Ngie and Menka according to field interviews expressed total ignorant about the existence of such nutritive species of fodder. It was equally observed that the growth of Guatemala and Bracharia is an innovation provided by the government since these cattle graziers do not have enough financial resources to pay for the improved seedlings of these fodder crops. In an attempt to promote this innovation however, it was observed that the efforts of the government are thwarted by some veterinary technicians who do not visit the grazing fields for on-the-spot appraisal. Also, most of the fodder seeds of Bracharia provided by the government for onward distribution to the graziers end up in offices and warehouses as most of the veterinary technicians do not go for field visits.

In view of this immense institutional lapses observed on the field, cattle graziers have persisted with unsustainable practices on the rangelands such as the burning of the grazing field during the drier season as a means to eliminate the bracken fern and provide an opportunity for fresh pasture to 
sprout up with the approach of the first rains. The continuous practice of transhumance especially in the drier season into the valleys which often results in farmer graziers conflicts in the study area.

Away from these unsustainable practices observed, it was noted that the need for intensification and diversification was very strong in the minds of the rural cattle graziers as paddocking is another growing diversification technique carried out by the livestock rearers. The paddock system was observed to be limited to the cattle and sheep graziers. The animals were equally observed to graze together or separately on open grazing land in flocks during the day and retire in the evening to pass the night in the paddocks. It was noted that those using this system are graziers that initially operated the activity on a small scale where they could easily tether the animals and tied them behind their houses at night. As the animal population increased, a change became imperative leading to the creation of paddocks. However, it was disclosed that the essence of this paddock system is to prevent the animals from wondering and straying at uncontrolled hours unlike purposefully keeping borrowed or own animals to render a piece of land plot fertile for crop cultivation.

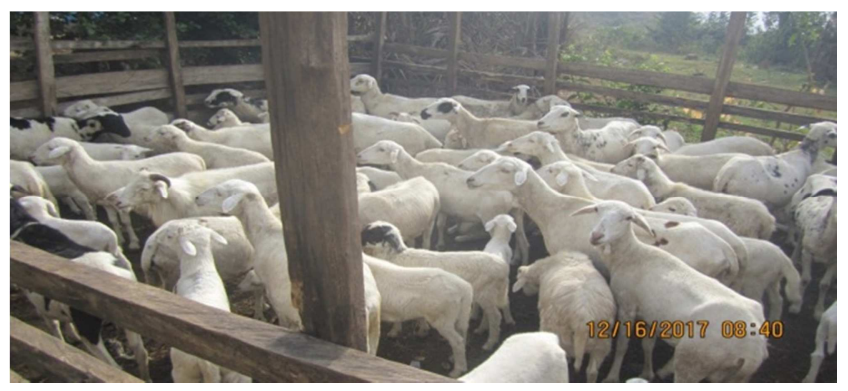

Source: Fieldwork (2017)

Figure 4. Sheep in paddock in the Upper Menka Highlands of Momo Division.

\section{Conclusion}

Cattle grazing remain one of the important livelihood assets of the rural communities of Momo Division especially the Fulani grazier which is their main source of livelihood. It has been established that this activity is being threatened both from the natural and human occupation of the landscape. In a bit to give life a meaning, these cattle graziers have been exploiting the rangelands using the most unsustainable practices at their disposal which further render the highlands vulnerable to the animal population.

As the cattle grazing activity in these highland areas of Cameroon provide income to the government, it is recommended that the government intensify efforts on improving on the grazing fields through training, sensitization, seminars and financial support to these cattle graziers whose eyes and minds are oriented toward using the most unsustainable practices aimed at achieving short term pasture and cattle yield without taking into consideration the long term feedbacks on their activity.

\section{References}

[1] Tassah I. T. \& Lambi M. C. (2014); Topographic Constraints and Agricultural Production in the Widikum-Menka Highlands, North West Region of Cameroon. In the African Journal of Social Sciences, Vol. 5, No 3, November 2014. Pg 16-29.

[2] Nkwemo E. A. and Tankie Q. S (2017): Grazing land Dynamics and the Adaptations of Pastoralists in the SabgaBamunka area, Cameroon in the African Journal of Social Sciences Vol. 8, No. 1, February 2017 pp. 30-46.

[3] FAO (2002): Food and Agricultural Organization Annual Reports.

[4] Becha N. F. (2013): Natural Resource Degradation: Management Options for Sustainable Livelihood in Widikum Sub-Division, North West Region of Cameroon. Unpublished M.Sc. Thesis, University of Buea, Cameroon.

[5] Sriskandarajah, Waren D. M., (1994): Using Indigenous Knowledge (1991) in Agricultural Development. In 127 World Bank decision papers.

[6] Thomas Sun p., (1998): Land and Water Resource Management in Asia. An EDI Policy seminar report \#20, Organised by the Economic Development Institute of the World Bank.

[7] BIFAD (1990 January): Sustainable Agriculture Information Exchange. Newsletter 1(1). Washington, USA.

[8] Gilberto C. Gallopin (2006): Linkages between Vulnerability, Resilience and Adaptive Capacity. Global Environmental Change 16 (2006), pp. 293-303.

[9] Tassah Ivo Tawe and Akenji Victorine Neh (2018). The Implications of Unsustainable Agricultural Land Resources Exploitation in the Widikum-Menka Highlands, North West Cameroon. International Journal of Law and Society. Vol. 1, No. 1, 2018, pp. 34-45.

http:/www.sciencepublishinggroup.com/j/ijls doi: 10.11648/j.ijls.20180101.15

[10] Ndenecho E. Neba. (2010). Integrating Local Livelihood Sustenance Activities in Protected Area Management: The case of Korup National Park, Cameroon. In African Jjournal of Social Sciences Vol. 1, Number 2, p 23. 